\title{
Glucagon physiology and pathophysiology in the light of new advances
}

\author{
R. H. Unger \\ Veterans Administration Medical Center and The University of Texas Health Science Center at Dallas, Dallas, Texas, USA
}

\begin{abstract}
Summary. Recent advances in the understanding of glucagoninsulin relationships at the level of the islets of Langerhans and of hepatic fuel metabolism are reviewed and their impact on our understanding of glucagon physiology and pathophysiology is considered. It now appears that $\alpha$ cells can respond directly to hyperglycaemia in the absence of insulin and $\beta$ cells, but that antecedent hyperglycaemia masks or attenuates this response. Insulin appears to exert ongoing release inhibition upon glucagon secretion, probably via the intra-islet microvascular system that connects $\beta$ cells to $\alpha$ cells. Diabetic hyperglucagonemia in insulin deficient states appears to be secondary to lack of the restraining influence of insulin. The $\alpha$ cell response to glucopenia, by contrast, may be in large part
\end{abstract}

mediated by release of noradrenaline from nerve endings in contact with $\alpha$ cells. Glucagon's action on glucose and ketone production by hepatocytes is mediated by increase in cyclicAMP-dependent protein kinase. The opposing action of insulin upon glucagon-mediated events probably occurs largely at this level. Consequently, when glucagon secretion or action is blocked, cyclic-AMP-dependent protein kinase activity is low even in the absence of insulin, explaining why marked glucose and ketone production is absent in bihormonal deficiency states.

Key words: Glucagon, diabetes, noradrenaline, insulin, fructose-2,6-bisphosphate, cyclic AMP-dependent protein kinase.
Although in certain respects glucagon is the most fully understood of the polypeptide hormones, ironically it has also been the most controversial. However, recently gained insights into insulin-glucagon interactions at both the level of the islets of Langerhans and of hepatic target cells have served to clarify certain of the disputed issues concerning glucagon's role in normal and diabetic fuel metabolism. In this communication controversial questions concerning insulin-glucagon interactions at two controversial sites, the islets of Langerhans and the hepatocytes, are re-examined in the light of information not available at the time of more comprehensive recent reviews $[1,2]$.

\section{Insulin-glucagon relationships within the islets of Langerhans}

\section{Glucose and the $\alpha$ cell}

Regulation of normal fuel homeostasis requires appropriate reactions of $\beta$ and $\alpha$ cells to a spectrum of physiological events. While the various signals that elicit such reactions have been difficult to sort out, clearly the overriding signal to both $\alpha$ and $\beta$ cells is the ambient glucose concentration, changes of which elicit a reciprocal response of insulin and glucagon (Fig.1). The mechanism by which changes in extracellular glucose concentration influence glucagon secretion has been controversial. It is unclear whether $\alpha$ cells sense and respond directly to glycaemic change or if, as recently proposed [3, 4], insulin, an inhibitor of glucagon secretion [5], mediates their response. According to the latter hypothesis, hyperglycaemia suppresses glucagon by stimulating insulin secretion, while hypoglycaemia stimu- lates glucagon by suppressing insulin secretion. The idea of insulin mediation of glucagon responses to glycaemic changes was buttressed by the fact that suppression of $\alpha$ cells by glucose had never been demonstrated in the absence of $\beta$ cells and insulin; $\alpha$ cells that lack contact with $\beta$ cells [e.g. those of patients with Type 1 (insulin-dependent) diabetes and of alloxan-diabetic dogs (Fig. 2a) and those in the gastric fundus of dogs or in a glucagonoma] could be suppressed by insulin but not by glucose [6-11]. Recently, however, it was shown

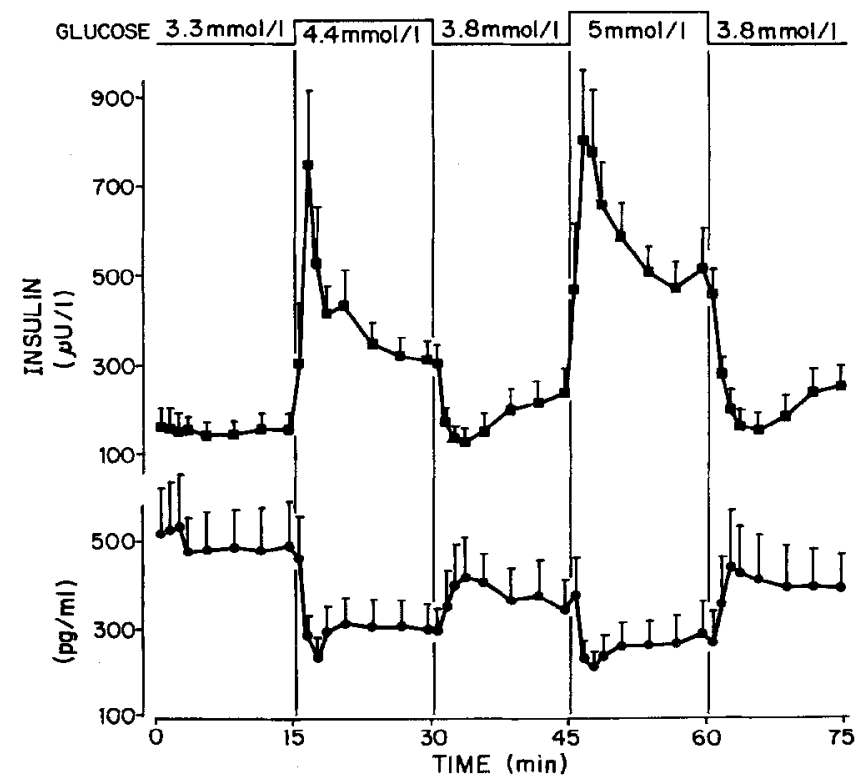

Fig. 1. A demonstration of the promt and reciprocal nature of the insulin ( concentration in the isolated perfused dog pancreas. (Unpublished work by K Kawai and RH Unger reproduced from [42]) 


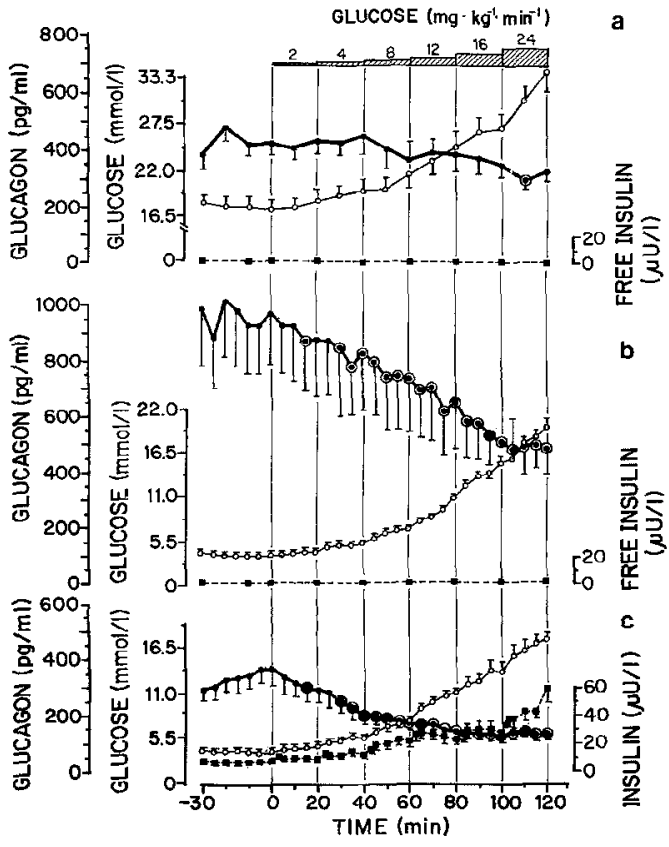

Fig. 2 a-c. A comparison of the glucagon response $(\longrightarrow)$ to progressively increasing rate of glucose infusion in a insulin-deprived alloxan-diabetic dogs with hyperglycaemia, b the same insulin-deprived alloxan-diabetic dogs pretreated with phloridzin to eliminate hyperglycaemia and $\mathbf{c}$ non-diabetic phloridzinized dogs. Glucagon levels that differ significantly $(p<0.05)$ from the basline value are circled. Glucose levels are represented by $\mathrm{O}-\mathrm{O}$ and insulin by $-\mathrm{a}$. The suppression of glucagon observed in $b$ in the absence of insulin or $\beta$ cells is consistent with an intrinsic glucose sensing system for $\alpha$ cells. The fact that glucose-induced suppression of glucagon in B stops when glucagon levels have reached the basal levels of unphloridzinized insulin-deprived diabetic dogs a suggests that in the latter group the hyperglycaemia has already achieved maximal glucagon suppression and that the residual hyperglucagonaemia is the consequence of absence of insulin-mediated glucagon suppression (Fig. 3). (Reprinted with permission of Proc Natl Acad Sci USA [12])

that the hyperglucagonaemia of insulin-deprived alloxan-diabetc dogs made normoglycemic by pretreatment with the glucuretic agent, phloridzin, responds normally to small increments in glucose [12] (Fig. 2b). Thus, glucose can suppress pancreatic $\alpha$ cells in the absence of $\beta$ cells and insulin provided there is no ambient hyperglycaemia. Hyperglycaemia produces an apparent glucose unresponsiveness of $\alpha$ cells probably by preempting and/or down-regulating the glucose sensing sites that mediate the negative glucagon secretory response to a rise in glucose. It is probable that these cells have responded already to glucose; the hyperglucagonaemia that persists despite the hyperglycaemia is the consequence of insulin deficiency and can be fully reduced to normal by insulin.

\section{Insulin and the $\alpha$ cell}

Despite the evidence that insulin is a potent inhibitor of glucagon secretion [3], the regulatory role of this effect upon $\alpha$-cell function has been uncertain. Two recent reports seem to have clarified this point, at least in the rat. Firstly, studies of the microcirculation of the rat islet indicate that blood flows from the $\beta$ cell-rich islet medulla

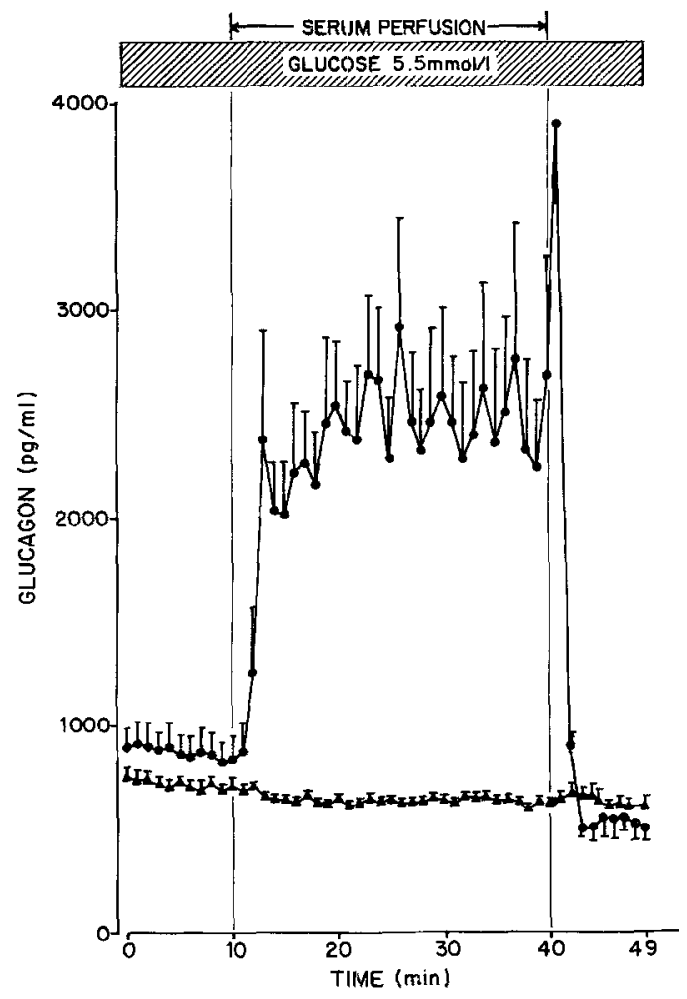

Fig. 3. The effect of a potent guinea pig anti-insulin serum (or nonimmune guinea pig serum ( isolated perfused rat pancreas. The antiserum is known to be capable of complete neutralization of up to $20 \mathrm{mU}$ within $1 \mathrm{~min}$ under the conditions that pertain in this nonrecirculating perfusion system. The rapidity of the on-off is consistent with neutralization of insulin in the microcirculation of the islets. (Reprinted with permission of the J Clin Invest [14])

to its $\alpha$ cell-rich cortex before leaving the islet [13]. $\alpha$ cells are thus exposed to the highest insulin concentration in the body. Secondly, single pass perfusion of normal rat pancreas with a potent neutralizing anti-insulin serum results in marked hyperglucagonaemia (Fig.3) [14]. The rapidity of this effect suggests that it is the consequence of neutralization within the islet microvasculature of insulin en route from $\beta$ cells to $\alpha$ cells and does not involve neutralization of insulin in the islet interstitium. It would seem that insulin within the islet microcirculation acts as a release-inhibiting factor of glucagon. An action of insulin on $\alpha$ cells via interstitial pathways cannot be excluded, but remains to be clearly established.

\section{Glucopenia and the $\alpha$ cells}

The mechanism by which glucopenia stimulates glucagon secretion has also been controversial. Simple lack of glucose [15] and/or its metabolites and/or reduction of insulin-mediated $\alpha$-cell suppression [3, 4] in the islet have been favoured explanations. However, recent work in the rat raises the possibility of a novel mechanism. The $\alpha$-adrenergic blocker phentolamine was 
found to reduce by about $70 \%$ the effect of glucopenia upon glucagon secretion in the isolated perfused pancreas of normal rats [16]. This suggests an adrenergically mediated system within the pancreas that senses and responds to glucopenia without any input from centres in the hypothalmus, which previously were believed to control all sympathetic regulation of islet cell secretion [17]. Preliminary evidence suggests that loss of the glucagon response to glucopenia in the perfused pancreas of streptozotocin-diabetic rats may be, in part, a consequence of damage to this adrenergically mediated system.

To summarize current concepts of $\beta$ - $\alpha$ cell relationships, the $\alpha$ cells of the rat are under the constant restraining influence of insulin within the islet microcirculation in the highest concentrations in the body. $\alpha$ cells can sense and respond normally to a rise in glucose concentration in the complete absence of $\beta$ cells and insulin. Glucopenia, on the other hand, stimulates glucagon secretion largely (but not entirely) via an intrapancreatic $\alpha$-adrenergic mechanism that operates independently of the central nervous system.

\section{Glucagon-insulin relationship in the liver}

A host of pathophysiological and clinical observations [18-22] indicate that hepatic over-production of glucose and ketones in the insulin-deficient state cannot occur unless glucagon is present, i.e. that insulin lack produces the catabolic cascade in the liver not directly but via glucagon-mediated mechanisms. This, the so-called "bihormonal abnormality hypothesis" of diabetes mellitus [23], has been perhaps the most controversial of recent glucagon-related issues. Now, however, it can be readily explained at the molecular level.

\section{The molecular physiology of glucagon and insulin}

(Figs. 4 and 5)

Within seconds after glucagon interacts with its receptor on liver cells, adenylate cyclase is activated and intracellular cyclic AMP concentrations rise. The increase in cytosolic cyclic AMP activates the all-important cyclic AMP-dependent protein kinase which, by phosphorylating certain key enzymes, induces the major hepatic actions of glucagon (stimulation of glycogenolysis, gluconeogenesis and ketogenesis and inhibition of glycogen synthesis, glycolysis and lipogenesis). As depicted in Figure 4, cyclic AMP-dependent protein kinase influences glycogen metabolism by phosphorylating (and thus activating) phosphorylase, the rate-limiting enzyme of glycogenolysis, and by phosphorylating (and thus inactivating) glycogen synthase [24]. Glycogenolysis is thereby increased and glycogenesis inhibited. Insulin opposes this action largely by reducing cyclic AMP-dependent protein kinase activity [25]. (It may also oppose glucagon by increasing the activity of phosphodiesterase, the enzyme that degrades cyclicyclic AMP [26].) In any case, when insulin is not present, the unopposed action of glucagon greatly increases cyclic
AMP and cyclic AMP-dependent protein kinase and initiates the catabolic cascade (Fig. 5). But, if glucagon is not present cyclic AMP and cyclic AMP-dependent kinase activity are low and a major site of insulin action on hepatic fuel metabolism is eliminated (Fig.5). This explains why the excessive hepatic fuel production that characterizes the insulin-deficient state does not occur in the total absence of glucagon.

Increased cyclic AMP-dependent protein kinase activity augments gluconeogenesis and ketone production by the same mechanism, i.e. phosphorylation of key proteins (Fig.4). The key protein in this case is the bifunctional enzyme that controls the level of fructose2,6-bisphosphate $\left(\mathrm{F}-2,6-\mathrm{P}_{2}\right)$, the recently discovered regulator of glycolysis and gluconeogenesis [27-29]. When glucagon levels are high relative to insulin and the enzyme is in a phosphorylated state, it acts as a fructose-2,6-bisphosphatase and lowers the levels of F$2,6-\mathrm{P}_{2}$ within the hepatocyte. This increases gluconeogenesis, thus explaining the increase in hepatic glucose production from non-glucose sources. Low F-2,6-P $\mathbf{P}_{2}$ levels also block glycolysis, which reduces the flow of 3-carbon fragments [30], the substrate for fatty acid synthesis (Fig. 4). In addition to substrate depletion, glucagon reduces lipogenesis by inhibiting acetyl-carboxylase activity [31], probably via a phosphorylation mechanism [32]. The reduction in lipogenesis is responsible for the increased ketogenesis. The initial product of fatty synthesis, malonyl-CoA, is the normal inhibitor of carnitine palmitoyl transferase-1 [33], the enzyme that transesterifies fatty acyl-CoA to fatty acyl carnitine, in which form fatty acids can cross into the mitochondria, the site of oxidation to ketones [34]. Depletion of malonyl-CoA by reduction in lipogenesis removes this normal restraint upon ketogenesis [35]. In addition, glucagon increases hepatic carnitine levels via an unknown mechanism [36]. Finally, the lack of insulin increases the availability of non-esterified fatty acids to the liver for oxidation to ketones through diminished insulin-mediated inhibition of lipolysis in adipocytes. As mentioned, insulin reverses all these changes by reducing the activity of cyclic AMP-dependent protein kinase (Fig. 4).

Finally, demonstration of the remarkable potency of glucagon action on the liver explains how over-production of glucose and ketones may occur in insulin-deprived depancreatized patients considered to be deficient in glucagon [37]. Glucagon in concentrations as low as $10^{-13} \mathrm{M}[38]$ reportedly reduces intrahepatic $\mathrm{F}$ $2,6-\mathrm{P}_{2}$ levels. This is well below the sensitivity of radioimmunoassays and would account for the fact that seemingly hypoglucagonaemic depancreatized patients developed diabetic ketoacidosis [37]. (However, more recent studies in such patients report glucagon levels to be in the normal or low-normal range $[39,40]$.)

To summarize, the fact that insulin's major metabolic effect on hepatocytes is to oppose glucagon explains why the presence of glucagon is required for the full metabolic expression of the syndrome of insulin-dependent diabetes mellitus. When glucagon is suppressed or inactivated [41], insulin-dependent diabetes mellitus is, 

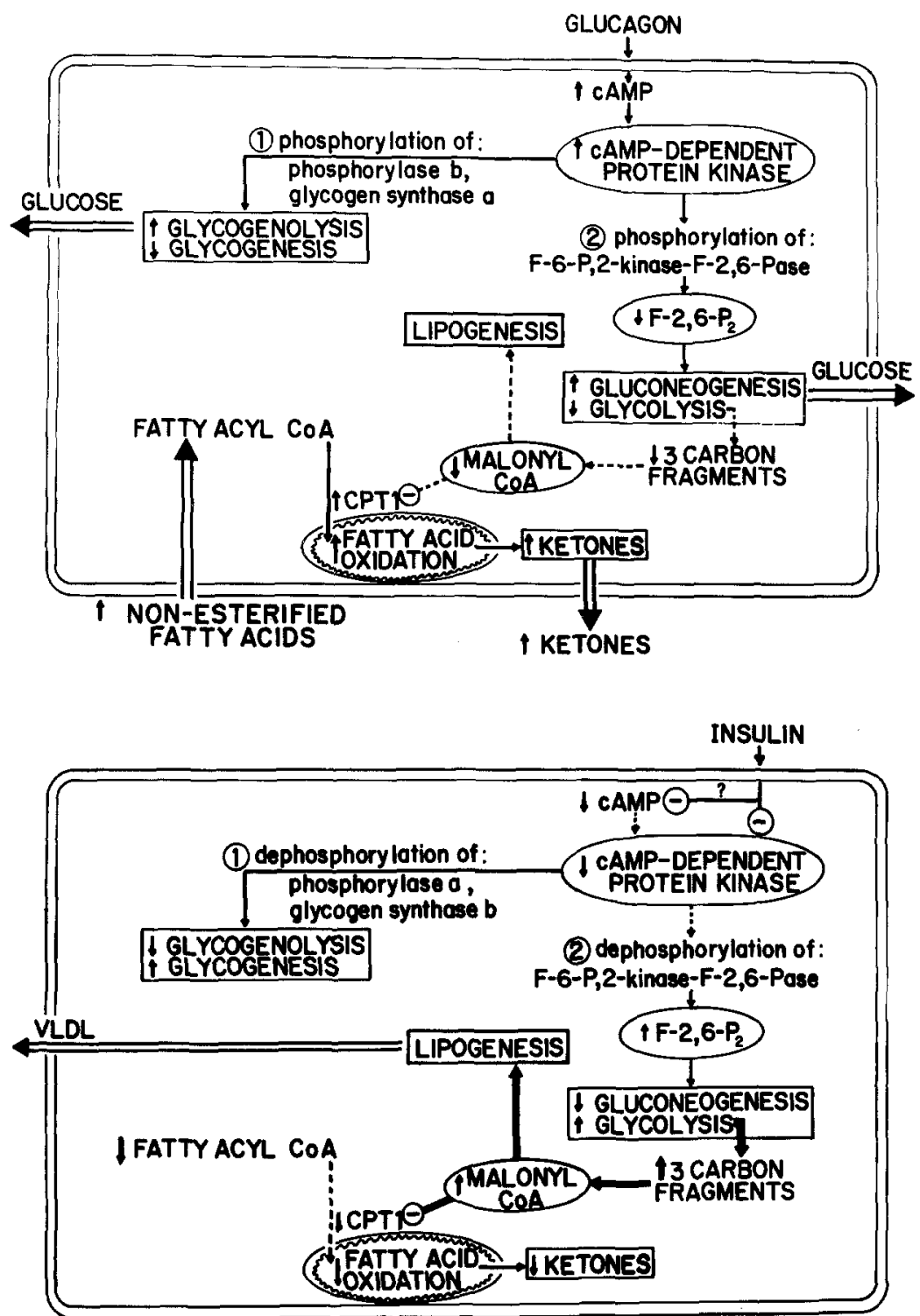

I NON-ESTERIFIED

FATTY ACIDS

Fig.4. A panoramic perspective of the major sites of glucagon-insulin interactions at the hepatocyte. The upper panel depicts the unopposed effects of glucagon and the lower panel the opposing actions of insulin. $\mathrm{CPT}=$ carnitine palmitoyl transferase. (Reprinted with permission from Diabetes Annual)

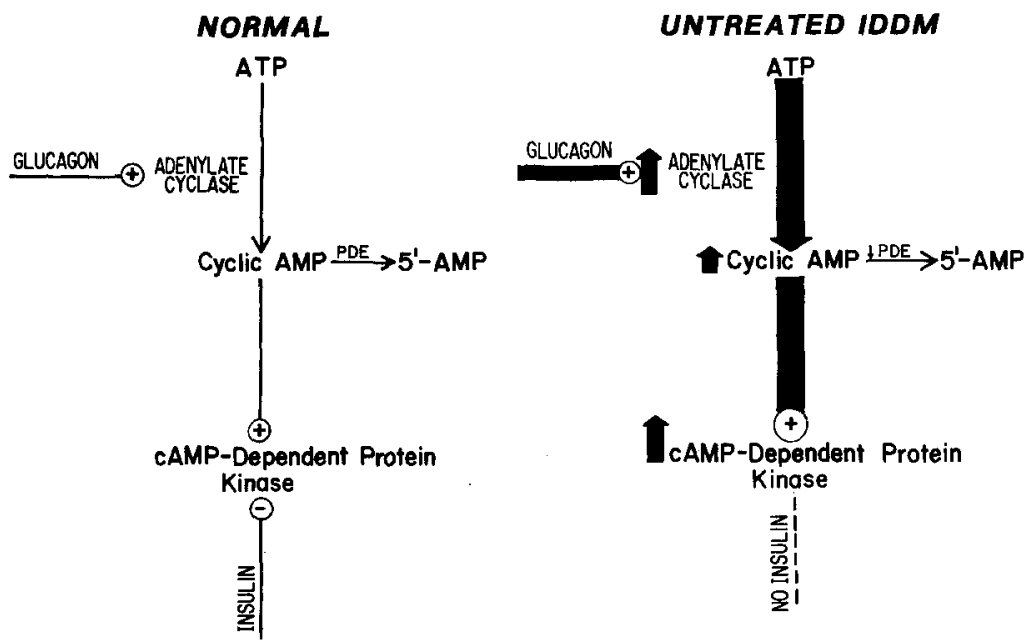

GLUCAGON DEFICIENCY

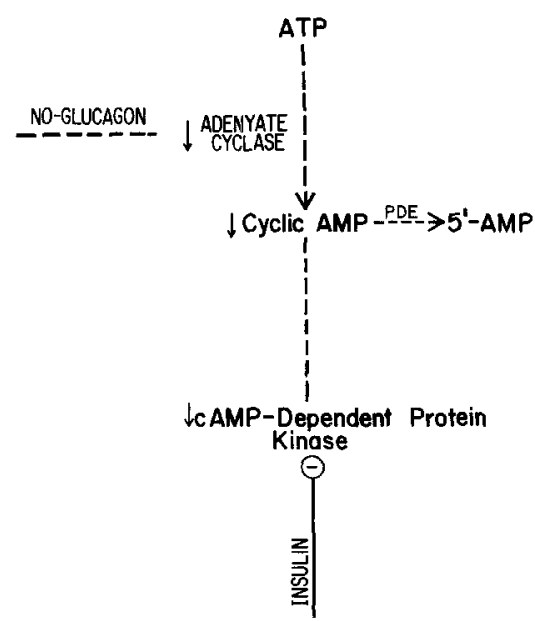

Fig.5. The probable sites of insulin opposition to glucagon action in the hepatocyte. The principal site of opposition appears to be at the level of cyclic AMP-dependent protein kinase, although insulin may also increase phosphodiesterase activity (not shown), thereby lowering cyclic AMP levels. The lefthand panel portrays normal glucagon-insulin interaction at this level; the middle panel glucagon action unopposed by insulin, as would pertain in insulin-deficient states; the righthand panel depicts and explains why insulin's hepatic influence is minimal when glucagon is not present 
in a sense, "converted" to a syndrome more compatible with the clinical definition of non-insulin-dependent diabetes [42].

\section{References}

1. Unger RH (1981) The milieu interieur and the islets of Langerhans. Diabetologia 20: 1-11

2. Unger RH, Orci L (1981) Glucagon and the A-cell. Physiology and pathophysiology. N Engl J Med 304: 1518-1524 and 1575-1580

3. Unger RH (1983) Insulin-glucagon relationships in the defense against hypoglycaemia. Diabetes 32: 575-583

4. Samols E (1983) Glucagon and insulin secretion. In: Lefebvre PJ (ed) Glucagon I. Springer, Berlin Heidelberg New York Tokyo, pp 485-518

5. Samols E, Tyler J, Marks V (1972) Glucagon-insulin interrelationships. In: Lefèbvre PI, Unger RH (eds) Glucagon. Molecular physiology, clinical and therapeutic implications. Pergamon, Oxford New York Toronto Sydney, pp 151-173

6. Raskin P, Aydin I, Unger RH (1976) Effect of insulin on the exaggerated glucagon response to arginine stimulation in diabetes mellitus. Diabetes 25: 227-229

7. Braaten JT, Faloona GR, Unger RH (1974) The effect of insulin on the alpha-cell response to hyperglycaemia in long-standing alloxan diabetes. J Clin Invest 53: 1017-1021

8. Blazquez E, Munoz-Barragon L, Patton GS, Orci L, Dobbs RE, Unger RH (1976) Gastric A-cell function in insulin-deprived depancreatized dogs. Endocrinology 99: 1182-1188

9. Lefèbvre PJ, Luyckx AS (1978) Glucagon and insulin in the regulation of glucagon release from the isolated perfused dog stomach. Endocrinology 103: 1579-1582

10. Tiengo A, Nosadini R, Del Prato S, Spina P, Devide A, Riva F, Crepaldi G (1978) Arginine and insulin-induced glucagon secretion and fasting ketogenesis in diabetics with or without partial or total pancreatectomy. Diabetologia 15: 276

11. Gerich JE, Langlois M, Noacca C, Lorenzi M, Karam JH, Forsham P (1976) Comparison of the suppressive effects of elevated plasma glucose and free fatty acid levels on glucagon secretion on normal and insulin-dependent diabetic subjects. Evidence for selected alpha cell insensitivity to glucose in diabetes mellitus. J Clin Invest 58: 320-325

12. Starke A, Grundy S, McGarry JD, Unger RH (1985) Correction of hyperglycaemia by inducing renal malabsorption of glucose restores the glucagon response to glucose in insulin-deficient dogs: Implications for human diabetes. Proc Natl Acad Sci USA 82: 1544-1546

13. Bonner-Weir S, Orci L (1982) New perspectives on the microvasculature of the islets of Langerhans in the rat. Diabetes 31: 883-889

14. Maruyama H, Hisatomi A, Orci L, Grodsky GM, Unger RH (1984) Insulin within islets is a physiologic glucagon release inhibitor. J Clin Invest 74: 2296-2299

15. Edwards JC, Hellerstrom C, Petersson B, Taylor KW (1972) Oxidation of glucose and fatty acids in normal and $\mathrm{A}_{2}$-cell rich pancreatic islets isolated from guinea-pigs. Diabetologia 8: 93-98

16. Hisatomi A, Maruyama H, Orci L, Vasko M, Unger RH (1985) Adrenergically mediated intrapancreatic control of the glucagon response to glucopenia in the isolated rat pancreas. J Clin Invest 75: $420-426$

17. Frohman LA, Bernardis LL (1971) Effect of hypothalamic stimulation on plasma glucose, insulin and glucagon levels. Am J Physiol 221: 1596-1603

18. Dobbs RE, Sakurai H, Sasaki H, Faloona GR, Valverde I, Baetens D, Orci L, Unger RH (1975) Glucagon: role in the hyperglycaemia of diabetes mellitus. Science 187: 544-547

19. Gerich JE, Lorenzi M, Bier DM, Schneider V, Tsalikian E, Karam JH, Forsham PH (1975) Prevention of human diabetic ketoacidosis by somatostatin: Evidence for an essential role of glucagon. $\mathrm{N}$ Engl J Med 292: 985-989

20. Cherrington AD, Lacy WW, Chiasson JL (1978) Effect of glucagon on glucose production during insulin deficiency in the dog. $\mathrm{J}$ Clin Invest 62: 664-677
21. Nakabayashi H, Dobbs RE, Unger RH (1978) The role of glucagon deficiency in the Houssay phenomenon of dogs. J Clin Invest 61: $1355-1362$

22. Santeusanio $F$, Massi-Renedetti $M$, Angeletti $G$, Calabrese $G$, Bueti A, Brunetti P (1981) Glucagon and carbohydrate disorder in a totally pancreatectomized man (a study with the aid of an artificial endocrine pancreas). J Endocrinol Invest 4:93-96

23. Unger RH, Orci L (1975) The essential role of glucagon in the pathogenesis of diabetes mellitus. Lancet 1: 14-16

24. Stalmans W (1983) Glucagon and liver glycogen metabolism. In: Lefèbvre PJ (ed) Glucagon I. Springer, Berlin Heidelberg New York Tokyo, pp 291-314

25. Gabbay RA, Lardy HA (1984) Site of insulin inhibition of cAMPstimulated glycogenolysis. cAMP-dependent protein kinase is affected independent of cAMP changes. J Biol Chem 259: $6052-6055$

26. Denton RM, Brownsey RW, Belsham GJ (1981) A partial view of the mechanism of insulin action. Diabetologia 21:347-362

27. Furuya E, Uyeda K (1981) A novel enzyme catalyzes the synthesis of activation factor from ATP and D-fructose-6-P. J Biol Chem 256: 7109-7112

28. Van Schaftingen E, Davies DR, Hers HG (1981) Inactivation of phosphofructokinase 2 by cyclic AMP-dependent protein kinase. Biochem Biophys Res Comm 103: 362-368

29. El-Maghrabi MR, Claus TH, Pilkis J, Fox E, Pilkis SJ (1982) Regulation of rat liver fructose-2,6-bisphosphatase. J Biol Chem 257 7603-7607

30. Foster DW, McGarry JD (1983) The metabolic derangements and treatment of diabetic ketoacidosis. N Engl J Med 309: 159-169

31. Cook GA, Nielsen RC, Hawkins RA, Mellmon MA, Lakshamanan MR, Veech RL (1977) Effect of glucagon on hepatic malonyl coenzyme A concentration and on lipid synthesis. J Biol Chem 252: $4421-4424$

32. Lent BA, Lee K-H, Kim K-H (1978) Regulation of rat liver acetylCoA carboxylase. Stimulation of phosphorylation and subsequent inactivation of liver acetyl-CoA carboxylase by cyclic $3^{\prime}$ : 5'-monophosphate and effect on the structure of the enzyme. J Biol Chem 253: 8149-8156

33. McGarry JD, Takabayashi Y, Foster DW (1978) The role of malonyl-CoA in the coordination of fatty acid synthesis and oxidation in isolated rat hepatocytes. $J$ Biol Chem 253: 8294-8300

34. McGarry JD, Leatherman GF, Foster DW (1978) Carnitine palmitoyltransferase I: the site of inhibition of hepatic fatty acid oxidation by malonyl-CoA. J Biol Chem 253: 4128-4136

35. McGarry JD, Foster DW (1980) Regulation of hepatic fatty acid oxidation and ketone body production. Annu Rev Biochem 49 : 395-420

36. McGarry JD, Robles-Valdes C, Foster DW (1975) Role of carnitine in hepatic ketogenesis. Proc Natl Acad Sci USA 72 : 4385-4388

37. Barnes AJ, Bloom SR (1976) Pancreatectomised man: a model for diabetes without glucagon. Lancet 1: 219-221

38. Richards CS, Furuya E, Uyeda K (1981) Regulation of fructose2,6- $P_{2}$ concentration in isolated hepatocytes. Biochem Biophys Res Comm 100: 1673-1679

39. Boden G, Master RW, Rezvani I, Palmer JP, Lobe TE, Owen OE (1980) Glucagon deficiency and hyperaminoacidemia after total pancreatectomy. J Clin Invest 65: 706-716

40. Holst JJ, Pedersen JH, Baldissera F, Stadil F (1983) Circulating glucagon after total pancreatectomy in man. Diabetologia 25 : 396-399

41. Johnson DG, Goebel CU, Hruby VJ, Bregman MD, Trivedi D (1982) Hyperglycaemia of diabetic rats decreased by a glucagon receptor antagonist. Science 215: 1115 1116

42. Unger RH, Foster DW (1985) Diabetes mellitus. In: Wilson J, Foster DW (eds) William's textbook of endocrinology, WB Saunders, Philadelphia, pp 1018-1080

\section{Dr. Roger H. Unger}

University of Texas

Health Science Center

5323 Harry Hines Boulevard 